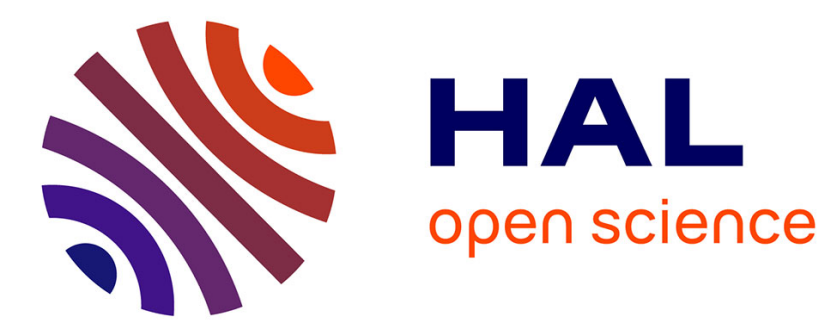

\title{
Inequality and Political Clientelism: Evidence from South India
}

Thomas Markussen

\section{To cite this version:}

Thomas Markussen. Inequality and Political Clientelism: Evidence from South India. The Journal of Development Studies, 2011, pp.1. 10.1080/00220388.2011.561330 . hal-00721635

\section{HAL Id: hal-00721635 \\ https://hal.science/hal-00721635}

Submitted on 29 Jul 2012

HAL is a multi-disciplinary open access archive for the deposit and dissemination of scientific research documents, whether they are published or not. The documents may come from teaching and research institutions in France or abroad, or from public or private research centers.
L'archive ouverte pluridisciplinaire HAL, est destinée au dépôt et à la diffusion de documents scientifiques de niveau recherche, publiés ou non, émanant des établissements d'enseignement et de recherche français ou étrangers, des laboratoires publics ou privés. 


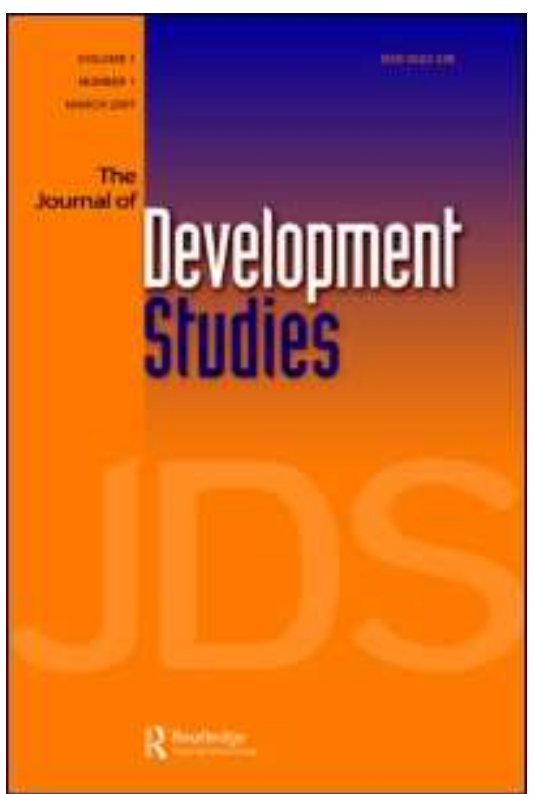

\section{Inequality and Political Clientelism: Evidence from South India}

\begin{tabular}{|r|l|}
\hline Journal: & Journal of Development Studies \\
\hline Manuscript ID: & FJDS-2010-May-0040.R1 \\
\hline Manuscript Type: & Original Manuscripts \\
\hline Keywords: & $\begin{array}{l}\text { South Asia < Geographical Area, Corruption < Government, State } \\
\text { Policy, \& Ideologies, Governance < Government, State Policy, \& } \\
\text { Ideologies, Poverty < Social Issues }\end{array}$ \\
\hline \multicolumn{2}{|c}{} \\
\hline
\end{tabular}

\section{SCHOLARONE ${ }^{m}$ \\ Manuscripts}




\title{
Inequality and Political Clientelism: Evidence from South India
}

October 2010

\begin{abstract}
Political parties can be vehicles for economic and social development in poor countries. They can also serve as rent seeking instruments. Uncovering how parties function is therefore key to establishing the preconditions for good governance. The paper discusses when and why clientelism on the basis of party affiliation may arise. Operationally, party-based clientelism is defined as a bias of public policy in favour of members of the governing political party. In a sample of local governments in India, party-based clientelism is shown to exist in two out of four states and to be strongly affected by economic inequality.
\end{abstract}

JEL classification: D31, D72, H7, O1

Keywords: Decentralization; Patronage; Clientelism; Inequality; Poverty; India 


\section{Introduction}

What is the role of political parties in local governments in developing countries? Are they forces for social change, or vehicles of patronage? The significance of democratically elected local councils in the developing world has grown dramatically in recent decades, making it essential to understand how local governments work and what explains the wide differences in performance between them (Manor 1999, Bardhan and Mookherjee 2006). Parties are key players in both local and national democracies almost everywhere and knowing how they function is essential for understanding the preconditions for good governance.

This paper investigates the role of political parties in local governments by studying clientelism based on party membership. The paper discusses why political clientelism might be important and argues that clientelism is likely to be most prevalent in underdeveloped and unequal communities. These conjectures are then tested on data from a survey of households and local governments in four South Indian states, namely Andhra Pradesh, Karnataka, Kerala and Tamil Nadu. A data set collected by Tim Besley, Rohini Pande and Vijayendra Rao is exploited (Besley et. al. 2004, Besley, Pande and Rao 2005a,b).

The operational definition of party-based clientelism is simply the strength of the partial correlation between membership in the party of the local government leader (the "President") and beneficiary status in a policy program. An advantage of this measure is that both party membership and beneficiary status are fairly objective and easy-to-measure variables. This stands in contrast to more commonly used measures of the quality of governance, which are often based on informants' subjective judgments. For example, the "Governance Indicators" published by the World Bank rely "exclusively on subjective or perceptions based measures of governance" (Kaufmann, Kraay and Mastruzzi 2004, p. 19). As Esteban and Ray (2006) point out, such measures 
are vulnerable to bias stemming from "rationalizations" of the observed performance of an economy.

Results show that in two out of the four states sampled (Kerala and Tamil Nadu), members of the President's party are more likely to benefit from an important poverty alleviation program than others, and that this effect is more important than other forms of discrimination, such as discrimination based on shared language, religion, caste or place of living. The presence of a strong interaction effect between economic inequality and party affiliation is demonstrated. In equal communities the influence of political clientelism is negligible but in unequal ones it is strong and quantitatively important. The main conclusions emerging from the paper are therefore, first, that party-based clientelism is empirically important, and second, that it is strongly affected by economic inequality. In Tamil Nadu, substantial heterogeneity across political parties in the employment of political clientelism is observed.

The paper is organised as follows: Section 2 discusses the significance and determinants of political clientelism. Section 3 reviews existing literature and section 4 gives background information and presents the dataset. Section 5 defines key variables. Section 6 provides descriptive statistics, and section 7 presents estimation results. Section 8 concludes.

\section{The potential importance of party based clientelism}

The politics of developing countries are often described as "clientelist" (e.g. Powell 1970, Lemarchand and Legg 1972, Kurer 1996, Wantchekon 2003). Clientelist politics is defined by the important role played by patron-client relations between political leaders (patrons) and specific groups or individuals (clients). In these relationships, public resources are allocated to clients in exchange for political support. Why does this phenomenon arise, and why does membership of political parties potentially play a role? 
From the point of view of ordinary citizens in poor countries, patron-client relationships serve as insurance devices and as means of obtaining access to scarce resources. It is perhaps more difficult to understand why political leaders in a democracy spend scarce resources on nurturing networks of clients. According to standard voting models, political leaders who care about re-election should focus on pleasing "swing voters", rather than loyalists (Downs 1957, Lindbeck and Weibull 1987). A main reason for a purely office-seeking candidate to deviate from these principles stems from the fact that candidates for political office need to run electoral campaigns. The services offered by clients may come in the form of campaign contributions, in addition to voting for the candidate. Even poor clients may contribute to electoral campaigns, by providing labour and by talking positively about the candidate in informal contexts. Grossman and Helpman (1996) show in a theoretical model how special interest groups and office-motivated politicians may trade campaign contributions for policy favours. Markussen (2009) discusses how this model can be adapted to describing the relationship between candidates for political office and rank-and-file party members.

Why would political clients want to be members of their patron's party? If party leaders' motive for maintaining networks of clients is to run effective campaigns, then it is natural to expect clients to be party members. The party is the organizational frame around political campaigns. Even if the motive for clientelism is simply vote buying, patrons may still favour clients who join their party because the secret ballot makes it difficult to target benefits to clients directly based on voting. Joining a party can be regarded as device for committing oneself to voting for the party since party members allow themselves to be exposed to increased amounts of propaganda, for example in party meetings (the participation in which can be monitored).

What determines the prevalence of political clientelism? Robinson and Verdier (2002) argue that it is fostered by low productivity and high inequality. The reason is, essentially, that these 


\title{
3. Related studies
}

\begin{abstract}
factors lower the price demanded by potential clients to enter into patron-client relationships, relative to the resources commanded by potential patrons. Low productivity leads to poverty, which increases the demand for the security offered by patrons. Inequality typically means that potential patrons command large amounts of resources relative to potential clients and are therefore more easily able to afford paying for their loyalty and services.
\end{abstract}

A number of authors have pointed to the importance of patron-client relations in general, and political clientelism in particular, in India (e.g. Kumar 1965, Weiner 1967, Brass 1990, Kohli 1990, Platteau 1995). Based on the large role played by the state in the provision of services and jobs, and on the high level of discretion enjoyed by officials in charge of distributing resources, Chandra (2004) describes India as a "patronage democracy".

The present paper follows in the footsteps of other empirical studies of capture and clientelism in local government in developing countries, summarised by Bardhan and Mookherjee (2006). A number of recent, empirical studies have in different ways focused on capture of local governments in India. Using the same dataset as here, Besley, Pande and Rao (2005a) find that GP politicians favour themselves and their fellow villagers in the allocation of public resources. For example, politician households are more likely than other households to benefit from the poverty alleviation program also studied in this paper (the BPL scheme). However, more educated politicians are less prone to nepotism. Besley, Pande and Rao also report that households affiliated with the local political leader's party are more likely than others to benefit from the program. However, this result is reported only in a footnote (p.24), without further discussion. The present paper follows up on that result by including a number of additional, relevant control variables, 
exploring interaction effects and heterogeneity across states and parties, and by offering interpretations.

Foster and Rosenzweig (2001) study local government provision of infrastructure in an India-wide sample of Gram Panchayats. They find that the introduction of local democracy reduces "elite capture", in the sense that it leads to more pro-landless public investment. In a similar vein, Bardhan and Mookherjee (2003) find that effective, political competition leads to pro-poor policies. They show in a study of local governments in West Bengal that more equal vote shares between the two major political blocs leads to higher levels of pro-poor land reform. Bardhan and Mookherjee (2006b) study the inter-GP and intra-village targeting of public resources to the poor in West Bengal and find few signs of elite capture within villages. On the other hand, they find that inter-GP allocation patterns are negatively correlated with poverty and inequality. They also investigate whether political favouritism affects inter-community allocations, but find no evidence in favour of this hypothesis. Bardhan et al. (2008) find similar results as Bardhan and Mookherjee (2006b), but also test whether respondents who voted for the party holding a majority in the GP receive additional resources. This hypothesis is not supported.

In sum, the literature on local government in India has in different ways dealt with government capture and clientelism along lines of class and political position. However, apart from the footnote in Besley, Pande and Rao (2005a), clientelism based on party affiliation is unexplored.

\section{Empirical setting and data}

\subsection{Background}

The empirical analysis exploits data from a survey of local governments, villages and households in rural areas of the four southernmost states of India: Andhra Pradesh, Karnataka, Kerala and Tamil Nadu. The constitutional basis for decentralised government in India has existed 
almost since the country gained independence in 1947, although in most states local governments were extremely weak until 1993 when the constitution was amended to reinforce the importance of local level democracy. The data used in the paper cover the lowest level of government, the Gram Panchayat (GP). A GP typically comprises between one and five villages, and has a few thousand inhabitants. The responsibilities of GPs vary between states, but in all states they serve at least two main functions. First, they provide public goods such as roads, street lights and water supply. Second, they select individual beneficiaries for state and federal welfare schemes (Besley et. al. 2005). It is this second function that we draw upon to investigate the effects of political clientelism.

The GP is subdivided into wards, and elections for GP councils are held at the ward level. The leader of the GP is called the President. In Andhra Pradesh and Tamil Nadu the President is elected directly, while in Karnataka and Kerala the elected ward representatives nominate the President. A council is elected for a fixed term of five years. Council members and Presidents can seek reelection, but the same seat cannot be reserved for the same group in two consecutive elections. In Andhra Pradesh and Karnataka, the political party affiliations of candidates in Gram Panchayat elections are not listed on the ballots (Karnataka State Election Commission, Suri 2002). Party members are not banned from running and in general most voters are likely to be aware of the party affiliation of leading candidates. Nevertheless, this rule may potentially affect the prevalence of party based clientelism by weakening the link between party-based election propaganda and electoral behaviour.

A genuinely competitive multiparty democracy is functioning in all four states, at state as well as local levels. The Indian National Congress (INC) is a central player in at least three of the sampled states. The only exception is Tamil Nadu, where the INC has not controlled the state government for several decades. Apart from that, the politics of the four states are dominated by different parties. In Andhra Pradesh, the regional Telugu Desam Party is the major player, 
challenged mainly by the INC. In Karnataka, the main competitors of the INC are the Janata Party, and the Bharatiya Janata Party (BJP). In Kerala, the main parties are the INC and the Communist Party of India (Marxist). In Tamil Nadu, several regional parties compete for power, the principal ones being the Dravida Munnetra Kazhagam (DMK) and the All India Anna Dravida Munnetra Kazhagam (AIADMK).

\subsection{Dataset}

The dataset used in the paper was collected in 2002. Sampling took place in several stages. Districts were selected in pairs on either side of state borders, so that district pairs with similar historical and socioeconomic characteristics were selected. More specifically, pairs of districts from two states were chosen so that each was part of the same political entity before the restructuring of state borders in 1956. Hence, the sample is not representative at the state level. Rather, the strength of the sampling strategy is that it builds in controls for historical factors that might influence current outcomes. Nine districts were sampled (one district entered the sample twice) and subsequently a total of 201 GPs were sampled from these districts. In each of the GPs, all villages were sampled if the GP had no more than three villages. If there were more than three villages, the President's village and two randomly selected villages were sampled. In each village a survey was administered to about three local politicians: the President, the Vice President and an ordinary council member. Village surveys were conducted to obtain data on local, public infrastructure, land and caste distribution. In a random sample of 101 GPs, household interviews were conducted in all the sampled villages. In total, 544 politician households and 5,180 ordinary household were interviewed. At least four scheduled caste or scheduled tribe households were sampled in each village. For further information on the sampling strategy, see World Bank (2005) and Besley, Pande and Rao (2005a,b). 
For the purposes of this study, data on households, as well as Presidents and villages are needed. Therefore, only those villages where household surveys were conducted are included in the analysis. The sample of politicians is used to construct variables such as whether respondents belong to the same party as the President, but the politician sample is not included in the sample used for estimation. Doing so would render the sample unrepresentative.

\section{Variable definitions}

The analysis follows Besley, Pande and Rao (2005a, 2007) and uses the allocation of Below Poverty Line (BPL) cards as the dependent variable. The BPL card was introduced by the national government in 1997 as attempt to improve targeting of the public food distribution system. BPL-card holders obtain the right to buy subsidised food from the public food distribution system. In addition, most GP administered housing-, employment and other welfare programs restrict access to BPL card holders. Having a BPL card is estimated to increase the income of an agricultural labourer household by about 5 percent in the four sampled states (Besley, Pande and Rao 2005a). Choosing BPL card holders is one of the most important tasks of the GP. The GP is allocated a fixed quota of BPL cards from authorities at the district level. It is subsequently supposed to carry out a household survey to determine who is eligible for the program, and produce a preliminary list of eligible households. The list is then officially required to be finalised in a village meeting open to all citizens, a so-called Gram Sabha. However, these meetings are often not held, and only about 22 percent of the respondents in the survey have ever attended one. In practice the GP council members and officials, in particular the President, have considerable discretion in choosing BPL beneficiaries. In sum, the dependent variable is an indicator variable taking the value one if the household has a BPL card. 
The explanatory variable of primary interest is an indicator taking the value one if the household head is a member of the same party as the President. The measure of political clientelism applied is then the partial correlation between membership in the President's party and beneficiary status in the BPL program.

The discussion in section 2 highlighted the potential importance of underdevelopment and inequality as factors leading to political clientelism. In terms of inequality, high quality data is available, since the village survey asked respondents to record the entire land distribution of their village. More precisely, respondents were asked to report how many households fall into each of the following brackets: no land, between 0 and 1 acres, between 1.1 and 5 acres, between 5.1 and 10 acres, between 10.1 and 25 acres, and above 25 acres. The GP land gini coefficient is estimated by pooling the data from the sampled villages in each GP. The interval midpoint value is assigned to each household in a bracket, and inequality is estimated. ${ }^{1}$ To measure levels of development, GPaverages of household heads' education in years and household ownership of durable goods are used (see notes to Table 1).

\section{Descriptive statistics}

Table 1 presents descriptive statistics on the sampled households. Some 22 percent of households are BPL card holders. The fraction of households where the household head is a member of a political party is 31 percent. This is a remarkably high level of political participation. Calculations based on the 1990-91 World Values Survey show that in most Western countries, less than 10 percent of the adult population are party members. ${ }^{2}$ Only about half of party members are members of the same party as the President.

There is considerable variation in land distribution among communities. The GP Gini coefficient of cultivated land has a mean of 0.63 and a standard deviation of 0.15 . 
Table 1 Descriptive Statistics

\begin{tabular}{|c|c|c|c|c|}
\hline & & olds & Hh head party & Hh head member of \\
\hline Variable & Mean & Std. Dev. & Mean & Mean \\
\hline BPL-card holder & 0.22 & 0.41 & 0.36 & 0.42 \\
\hline Hh head member of political party & 0.31 & 0.46 & 1.00 & 1.00 \\
\hline Hh head member of President's party & 0.14 & 0.34 & 0.44 & 1.00 \\
\hline Family political history & 0.06 & 0.23 & 0.11 & 0.09 \\
\hline Gram Panchayat gini of cultivated land & 0.63 & 0.15 & 0.66 & 0.65 \\
\hline Gram Panchayat landlessness rate & 0.37 & 0.22 & 0.43 & 0.42 \\
\hline Scheduled caste or scheduled tribe & 0.23 & 0.42 & 0.24 & 0.24 \\
\hline Head's education (years) & 3.42 & 4.14 & 3.72 & 3.14 \\
\hline Agricultural land owned (acres) & 2.07 & 4.38 & 1.79 & 1.55 \\
\hline Hh size & 5.33 & 2.39 & 5.30 & 5.27 \\
\hline Age of household head & 49.10 & 13.81 & 47.95 & 47.53 \\
\hline Durable goods (index)* & 11.67 & 13.01 & 12.70 & 11.54 \\
\hline Female household head & 0.12 & 0.32 & 0.09 & 0.08 \\
\hline Hh head unmarried & 0.01 & 0.12 & 0.02 & 0.02 \\
\hline Hh head divorced & 0.01 & 0.07 & 0.01 & 0.01 \\
\hline Hh head widowed & 0.13 & 0.33 & 0.10 & 0.08 \\
\hline Main source of income: & & & & \\
\hline Selfemployment in agriculture & 0.36 & 0.48 & 0.32 & 0.30 \\
\hline Agricultural labour & 0.25 & 0.43 & 0.22 & 0.24 \\
\hline Casual labour (coolie) & 0.18 & 0.39 & 0.23 & 0.25 \\
\hline Permanent wage labour & 0.07 & 0.26 & 0.08 & 0.06 \\
\hline Selfemployment in non-agriculture & 0.06 & 0.24 & 0.06 & 0.07 \\
\hline $\begin{array}{l}\text { Rents, remittances, interests, dividends and } \\
\text { pensions }\end{array}$ & 0.02 & 0.15 & 0.03 & 0.03 \\
\hline Other & 0.04 & 0.20 & 0.04 & 0.04 \\
\hline
\end{tabular}

\section{Note: $\mathrm{N}=5,180$.}

*This variable is a weighted sum of the durable goods owned by the households. I have not had access to price data which could bed used to construct weights, and the weights are therefore based on casual estimates of relative value (This method was also used by La Ferrara (2002) for constructing a key asset inequality variable for a sample of Tanzanian households. For overlapping goods, my weights are roughly proportional to hers). The weights are: Pressure cooker, fan, bicycle, pressure lamp, desert cooler: 2, Radio, transistor, cassette player: 3, Watch, black and white TV: 4, Sewing machine, music system, color TV, autorickshaw, refrigerator, freezer, washing machine, camera: 5, Motor cycle, moped, telephone set: 6, Motor car: 7.

Table 1 also presents descriptive statistics specifically for members of political parties, and for members of the President's party. Consistent with the view that party-based clientelism exists, party members, particularly members of the President's party, are much more likely than the average household to benefit from the BPL program. This key result is explored further in section 7.1 . 
Table 2: Party affiliation and beneficiary status in a poverty alleviation program

\begin{tabular}{|c|c|c|c|c|c|c|}
\hline & \multicolumn{6}{|c|}{ Dependent variable: Hh has BPL card } \\
\hline & \multirow{2}{*}{ All } & \multicolumn{2}{|r|}{ Andhra } & Karnataka & Kerala & $\begin{array}{l}\text { Tamil } \\
\text { Nadu }\end{array}$ \\
\hline & & 2SLS & OLS & OLS & OLS & OLS \\
\hline \multirow[t]{2}{*}{ Member of President's party } & 0.06 & 0.736 & -0.052 & 0.013 & 0.089 & 0.080 \\
\hline & $(2.67)^{* * *}$ & $(1.69)^{*}$ & $(1.06)$ & $(0.39)$ & $(2.42)^{* *}$ & $(1.83)^{*}$ \\
\hline \multirow[t]{2}{*}{ Member of other party } & 0.018 & 0.23 & -0.004 & -0.014 & 0.026 & -0.014 \\
\hline & $(0.92)$ & $(1.66)^{*}$ & $(0.09)$ & $(0.55)$ & $(0.81)$ & $(0.52)$ \\
\hline \multirow[t]{2}{*}{ Family political history } & -0.038 & -0.131 & 0.043 & -0.065 & 0.002 & -0.078 \\
\hline & $(1.94)^{*}$ & $(2.04)^{* *}$ & $(0.87)$ & $(2.77)^{* * *}$ & $(0.04)$ & $(2.10)^{* *}$ \\
\hline \multirow[t]{2}{*}{ Scheduled caste/scheduled tribe } & 0.115 & 0.084 & 0.041 & 0.062 & 0.228 & 0.122 \\
\hline & $(6.34)^{* * *}$ & $(2.94) * * *$ & $(0.76)$ & $(2.63)^{* *}$ & $(5.66) * * *$ & $(3.28) * * *$ \\
\hline \multirow[t]{2}{*}{ Education of head in years } & -0.003 & -0.002 & -0.005 & 0.000 & -0.004 & -0.007 \\
\hline & $(2.25)^{* *}$ & $(1.12)$ & $(1.26)$ & $(0.29)$ & $(0.87)$ & $(2.52)^{* *}$ \\
\hline \multirow[t]{2}{*}{ Agricultural land owned, acres } & -0.003 & -0.002 & -0.003 & -0.001 & -0.019 & -0.01 \\
\hline & $(2.34) * *$ & $(1.98)^{* *}$ & $(0.78)$ & $(1.25)$ & $(3.29) * * *$ & $(4.72) * * *$ \\
\hline \multirow[t]{2}{*}{ Household size } & 0.005 & 0.005 & 0.005 & 0.001 & 0.009 & 0.008 \\
\hline & $(2.23) * *$ & $(2.01)^{* *}$ & $(0.85)$ & $(0.57)$ & $(1.69)^{*}$ & $(1.43)$ \\
\hline \multirow[t]{2}{*}{ Age of head } & 0.001 & 0.001 & 0.000 & 0.001 & 0.002 & 0.000 \\
\hline & $(2.01)^{* *}$ & $(1.98) * *$ & $(0.08)$ & $(1.82)^{*}$ & $(1.62)$ & $(0.59)$ \\
\hline \multirow[t]{2}{*}{ Index of durable goods ownership } & -0.002 & -0.002 & 0.000 & -0.001 & -0.003 & 0.001 \\
\hline & $(5.58)^{* * *}$ & $(3.92) * * *$ & $(0.08)$ & $(1.88)^{*}$ & $(4.40) * * *$ & $(0.90)$ \\
\hline \multirow[t]{2}{*}{ Female household head } & 0.046 & 0.065 & 0.086 & 0.018 & 0.048 & -0.005 \\
\hline & $(1.91)^{*}$ & $(2.31)^{* *}$ & $(0.92)$ & $(0.91)$ & $(0.64)$ & $(0.09)$ \\
\hline \multirow[t]{2}{*}{ Same religion as President } & 0.032 & 0.033 & -0.041 & -0.012 & 0.045 & -0.032 \\
\hline & $(1.66)^{*}$ & $(1.40)$ & $(1.58)$ & $(0.36)$ & $(1.64)$ & $(1.00)$ \\
\hline \multirow[t]{2}{*}{ Same caste as President } & 0.037 & 0.028 & 0.081 & 0.031 & 0.067 & -0.031 \\
\hline & $(2.00) * *$ & $(1.40)$ & $(1.03)$ & $(1.75)^{*}$ & $(1.88)^{*}$ & $(1.09)$ \\
\hline \multirow[t]{2}{*}{ Same village as President } & 0.005 & & 0.040 & 0.002 & 0.027 & -0.023 \\
\hline & $(0.33)$ & & $(0.85)$ & $(0.08)$ & $(0.93)$ & $(0.85)$ \\
\hline \multirow[t]{2}{*}{ Same occupation as President } & 0.025 & & 0.005 & 0.013 & 0.024 & -0.006 \\
\hline & $(1.39)$ & & $(0.08)$ & $(0.73)$ & $(0.52)$ & $(0.24)$ \\
\hline \multirow[t]{2}{*}{ Same level of educ. as President } & -0.019 & & -0.088 & 0.015 & -0.016 & -0.013 \\
\hline & $(1.45)$ & & $(2.61)^{* *}$ & $(0.92)$ & $(0.55)$ & $(0.47)$ \\
\hline \multirow[t]{2}{*}{ Constant } & 0.068 & 0.336 & 0.292 & 0.037 & 0.003 & 0.217 \\
\hline & $(2.12) * *$ & $(1.78)^{*}$ & $(2.68)^{* *}$ & $(0.95)$ & $(0.04)$ & $(3.46)^{* * *}$ \\
\hline Fixed effects & GP & GP & GP & GP & GP & GP \\
\hline Observations & 4,844 & 4,844 & 594 & 1,715 & 1,198 & 1,337 \\
\hline R-squared & 0.36 & & 0.38 & 0.35 & 0.27 & 0.46 \\
\hline \multicolumn{2}{|c|}{ Hansen J-test of instrument exogeneity (p-value) } & 0.73 & & & & \\
\hline \multicolumn{2}{|c|}{ F-test of excluded variables in first-stage } & & & & & \\
\hline regression & & 4.24 & & & & \\
\hline
\end{tabular}

$\mathrm{t}$ statistics in parentheses. Standard errors are adjusted for clustering at the village level. In the 2SLS regression, membership of President's party is instrumented with indicators for living in the same village as the President and for having the same (non-political) occupation and level of education as the President, respectively. Indicators for marital status and main source of income are included but not shown.

* significant at $10 \%$; * significant at $5 \%$; *** significant at $1 \%$ 


\section{Estimation results}

\subsection{Existence of party-based clientelism}

Table 2 shows the results of estimating regression models for BPL beneficiary status. The first two regressions pool all observations, while the last four columns present separate regressions for each of the four states. In addition to the main variable of interest, membership of the President's party, a number of control variables are also included. First, we might worry that membership of the President's party is merely a proxy for the official eligibility criterion for participation in the program, which is poverty. To take account of this objection, a number of variables known to be correlated with poverty are introduced, namely: (i) whether the household belongs to a scheduled caste or a scheduled tribe, (ii) education of the household head in years, (iii) amount of agricultural land owned by the household, (iv) household size, (v) age, gender and marital status of the household head, (vi) an index of durable goods ownership, and (vii) dummies for the household's main source of income. To save space, coefficients on marital status and source of income are not shown. When these variables are introduced, most of them have the expected sign, and many are significant. As noted by Besley, Pande and Rao (2005) the significant effect of variables correlated with poverty indicates that, even if various sorts of capture and clientelism exist, GPs do in fact achieve some amount of targeting.

Second, we can imagine that membership of the President's party functions as a proxy for being a politician in the GP council. A variable measuring whether a member of the household's family holds or has held a political position is therefore introduced ("members of the family" are not necessarily members of the household). This variable enters with a negative coefficient. ${ }^{3}$

Third, it is necessary to check that membership of the President's party is more beneficial than membership of other parties. A dummy for being a member of other parties than the President's is therefore introduced. This variable enters with a positive sign, and it is significant in 
one specifications. In both regressions using the full sample, the point estimate of the coefficient on membership of other parties is much lower than the coefficient on membership of the President's party.

Fourth, it is possible to imagine that membership of the President's party is a proxy for other kinds of affiliation with the President, such as shared religion, caste, place of living, occupational- or educational background. To test this hypothesis, dummies for sharing religion, caste, occupation (apart from being the President), level of education and village of residence with the President are entered. ${ }^{4}$ The coefficients on the variables are in most cases smaller than the coefficient on membership of the President's party, although the hypothesis that the coefficients on membership of the President's party, same religion and same caste as the President are equal cannot be rejected according to statistical criteria. Same religion and same caste as the President are both significant in the first regression in table 2. This gives some indication that favouritism along religious and caste lines plays a role in the Panchayats, in line with the arguments made in Chandra (2004). On the other hand, there is no evidence of favouritism along educational, occupational or village lines.

Finally, to control for unobservable characteristics at the state, district or GP level, such as the total number of BPL cards allocated to districts and GPs, GP fixed effects are introduced.

The member of President's party-variable is positive and significant in both regressions using the full sample. Hence, the correlation between membership of the governing party and beneficiary status, reported in Table 1 , is robust to including the set of control variables. While the results in Table 2 are all based on linear probability models, qualitatively similar results emerge from using a probit model instead (results not shown). 


\subsection{Endogenous party membership}

We might worry that membership of the President's party is endogenous. Membership of the President's party could be affected by BPL beneficiary status if beneficiaries tend to join the President's party out of gratitude for receiving the BPL card, or because they read the benefits as a signal of the party's competence. In regression 2, indicators for sharing, respectively, occupationaland educational background and village of residence with the President are used as instruments for membership of the President's party. The idea is, first, that these variables may affect the decision to join the President's party. Citizens may feel best represented by a party leader with the same background as themselves. Second, the insignificant coefficients on the dummies for sharing village, occupation and educational background with the President in regression 1 indicate that these variables do not have a direct effect on the allocation of BPL cards. At the bottom of Table 2, tests of instrument performance are reported. First, the Hansen $J$ test reveals no evidence against the assumption of instrument exogeneity $(\mathrm{p}=.73)$. Second, an $F$-test of instrument relevance shows that the instruments are jointly significant in the first-stage regression $(\mathrm{p}=.01)$. The value of the $F$ statistic, however, is only 4.24. Staiger and Stock (1997) state that as a rule of thumb the $F$-value should be at least 10 . Hence, the instruments are somewhat weak. Results show that the coefficient on membership of the President's party remains positive and significant at the ten percent level. The main concerns are the fact that the coefficient is very imprecisely estimated (the standard error is .43) and that the point estimate is unexpectedly high. Membership of the President's party is estimated to increase the probability of holding a BPL card by 73 percentage points. The high estimate may result from the weak instruments (Stock and Yogo 2004). Still, the fact that the estimate is positive and significant strengthens the view that the correlation between membership of the President's party and BPL beneficiary status is not caused by reverse causality. In the analysis below we revert to treating membership of the President's party as exogenous. 


\subsection{Heterogeneity across states}

Regressions 3 to 6 in Table 2 reveal substantial heterogeneity across states in the prevalence of political clientelism. In Andhra Pradesh and Karnataka, there is no significant effect of membership of the President's party on BPL beneficiary status. In Kerala and Tamil Nadu, on the other hand, the effect is positive and significant. One potential explanation is based on the difference in electoral rules referred to above, which means that candidates in GP elections run on party labels in Kerala and Tamil Nadu, but not in Andhra Pradesh and Karnataka. However, as discussed, most candidates in Karnataka and Andhra Pradesh do in fact belong to political parties and the party affiliation of potential GP presidents is likely to be largely common knowledge. Therefore, this explanation may not be fully satisfactory.

Alternatively, variation between states may result from more fundamental differences in the development of patronage relations. Patron-client relations have been important in India since ancient times (e.g. , Kumar 1965, Platteau 1995). However, a transformation of the nature of these relations has been taking place for some time. As Graziano (1973) describes for Southern Italy, based on the concepts developed by Weingrod (1968), there has been a transition from "clientelism of the notables" to "political party-directed clientelism" (Widlund 2000 points out the relevance of this distinction for India). The most influential patrons used to be high-caste landowners, maintaining clientelist relations with local peasants based on the exchange of insurance and credit for labor and loyalty. Increasingly, however, the most important patrons are instead party leaders, exchanging public resources for political support. The mode of operation employed by the previously hegemonic Congress party arguably represents a way-station in this transition. The Congress in many cases exploited traditional patron-client relations by turning local patrons into clients of the party, and thereby gaining the clients of these persons as "vote banks" (e.g. Kohli 


\begin{abstract}
1987 p.62). Now, Kerala and Tamil Nadu were among the first states in India to overthrow the traditional Congress system. In Tamil Nadu, Congress lost control of the State Assembly in 1967 and has not regained it since. In Kerala, Congress first lost power already in 1957. The party has regained control of the State government a number of times, but the pace-setters in terms of policy as well as style of politics have been mostly been the CPI(M) (cf. Alexander 1989). In abandoning Congress hegemony, Kerala and Tamil Nadu arguably completed the transition from clientelism of the notables to party-based clientelism. Political clientelism is a strategy for political parties to obtain support, and to a large extent it was probably this strategy that parties in Kerala and Tamil Nadu used successfully to gain power. This may explain why party-based clientelism is particularly prevalent in these states.
\end{abstract}

Qualitative evidence on the importance of political clientelism in Kerala is provided by Platteau and Abraham (2002) who report that, although Kerala is famous for developmental achievements, its local government program "suffers from an important weakness in that it has become a platform for political favouritism in a country plagued by excessive party politicisation down to the local level" (p. 126). In a similar vein, Tharakan (2004) concludes that "the evolution of modern Kerala society and politics resulted in a process of party-politicisation of associational life, which subjected it to the clientelistic principle of winning support by way of partisan favours". In Tamil Nadu, Subramanian (1999, p.67) reports that “crucial Dravidianist policies (...) were clientelist as they targeted specific groups which gave the ruling party their support in return..". Widlund (2000) writes about the AIADMK party that "the members are aware of the patronage potential that comes with belonging to the ruling party and they expect to share the benefits".

In contrast, a traditional style of politics, where political parties use local notables as intermediaries, has until recently continued to dominate political life in Karnataka. (Crook and Manor 1998, Harriss 1999). Andhra Pradesh (AP) represents a mixed case. Harriss (1999) groups 
AP along with Karnataka as States with "middle caste/class dominated regimes, where the Congress has been effectively challenged but has not collapsed". In contrast, he groups Kerala and Tamil Nadu (along with West Bengal) as "states in which lower castes/classes are more strongly represented in political regimes where the Congress lost its dominance at an early stage". However, politics in Andhra Pradesh are in some respect similar to those in Tamil Nadu. A regional party (the TDP) has adopted a populist approach and effectively challenged the dominance of the Congress. Congress maintained a stronger role in AP than in Tamil Nadu, but the populist strategies of the TDP have in many ways been similar to the strategies of the Dravidian parties in Tamil Nadu. There may be a different reason why political clientelism was not a prominent feature of Gram Panchayat politics in Andhra Pradesh at the time of the survey. During this period, the TDP government in Andhra Pradesh focused heavily on implementing the so-called "Janmabhoomi" program. By introducing local water user group, women's groups and other special-purpose bodies, this program essentially promoted a parallel structure of local government, largely bypassing the panchayats. It is plausible that the TDP used the Janmabhoomi system, rather than the Gram Panchayats, to channel patronage to its supporters (Suri 2002, p.44).

\subsection{Heterogeneity across political parties}

Some political parties may engage more heavily in political clientelism than others. Table 3 investigates the effect of membership of the Presidents party separately for each of the four main parties in the two states where political clientelism was detected. The same set of control variables as in Table 2 is included. In Kerala, the table shows that the coefficient on membership of the President's party is roughly similar for Congress- and CPI(M) headed GPs. Both estimates are statistically insignificant, but this can be ascribed simply to the drop in sample size. The sizes of the coefficients are similar to the estimate for Kerala in Table 2. Hence, party-based clientelism appears 
Table 3: Political clientelism and President's party

\begin{tabular}{|c|c|c|c|c|}
\hline \multirow{3}{*}{$\begin{array}{l}\text { State } \\
\text { President's party }\end{array}$} & \multicolumn{4}{|c|}{ Dependent variable: Hh has BPL card } \\
\hline & \multicolumn{2}{|c|}{ Kerala } & \multicolumn{2}{|c|}{ Tamil Nadu } \\
\hline & Congress & $\mathrm{CPI}(\mathrm{M})$ & AIADMK & DMK \\
\hline Member of President's party & $\begin{array}{l}0.077 \\
(1.53)\end{array}$ & $\begin{array}{l}0.067 \\
(1.07)\end{array}$ & $\begin{array}{c}0.083 \\
(1.71)^{*}\end{array}$ & $\begin{array}{l}0.001 \\
(0.02)\end{array}$ \\
\hline Control variables as in table 2 & Yes & Yes & Yes & Yes \\
\hline Fixed effects & GP & GP & GP & GP \\
\hline Observations & 599 & 359 & 747 & 198 \\
\hline R-squared & 0.29 & 0.37 & 0.52 & 0.60 \\
\hline
\end{tabular}

One explanation may be that the AIADMK was in charge of the State government at the time. There may be more room for local leaders to hand out patronage when fellow party members are in charge at higher levels of government. However, the different styles of politics adopted by the two Dravidian parties may also play a role. Subramanian (1999) describe both parties as "populist", but distinguish between the "assertive" populism employed by the DMK and the "paternalist" populism of the AIADMK. Assertive populists mainly focus on distributing patronage in the form of jobs, reservations at universities and similar. Clients typically belong to the minority of subjects who command the minimum level of resources necessary to be able to benefit from this type of services. Paternalist populists, on the other hand, hand out patronage in the form of welfare goods to broad segments of the population. The distribution of BPL cards as patronage is typical of a paternalistbut not of an assertive populist party. Hence, the difference between DMK and AIADMK reported 
in Table 3 is consistent with Subramanians characterization of the two parties as, respectively, assertive- and paternalist populists.

\subsection{Determinants of political clientelism}

The discussion in section 2 suggests that inequality and low levels of economic development increase the incidence of political clientelism. Table 4 shows the results of entering measures of development and inequality, interacted with the member of President's party-variable into the BPL-allocation model. The regressions include the same controls as in columns 4 and 5 of table 2. The estimated coefficients on the control variables are not shown. In order to not loose the main effects of the GP-level measures of inequality and development, which are interesting in their own right, district fixed effects are used instead of GP fixed effects. GP fixed effects are reintroduced in regression 6. The entire sample is used. Very similar results emerge if only observations from Kerala an Tamil Nadu are included (not shown).

The first column of Table 3 reveals a significant and numerically strong, positive interaction between membership of the President's party and the land gini. In fact, the model predicts that in completely equal communities (land gini $=0$ ) there is a significant negative effect of being a member of the President's party (the coefficient on the same-party-as-President main effect is significant and negative). However, no GPs in the sample are close to complete equality. What should be emphasised is this: As GPs become more unequal, political clientelism is predicted to increase rapidly. Positive discrimination in favour of members of the President's party is estimated to be present in GPs with a land gini above 0.4. Note from Table 1 that the average land gini is 0.63. The coefficient on the main effect of the land gini is negative, suggesting that as inequality increases, households who are not members of the governing political party become less likely to receive a BPL card. 
Table 4: Determinants of party capture

\begin{tabular}{|c|c|c|c|c|c|c|}
\hline & \multicolumn{6}{|c|}{ Dependent variable: Household has BPL card } \\
\hline & OLS & OLS & OLS & OLS & 2SLS & 2SLS \\
\hline Member of President's party & $\begin{array}{c}-0.228 \\
(2.82)^{* * *}\end{array}$ & $\begin{array}{l}0.043 \\
(0.68)\end{array}$ & $\begin{array}{c}0.04 \\
(0.67)\end{array}$ & $\begin{array}{l}-0.207 \\
(2.52)^{* *}\end{array}$ & $\begin{array}{l}-0.113 \\
(0.98)\end{array}$ & $\begin{array}{l}-0.145 \\
(1.65)^{*}\end{array}$ \\
\hline Member of President's party*Land gini & $\begin{array}{c}0.567 \\
(4.23) * * *\end{array}$ & & & $\begin{array}{c}0.689 \\
(4.04) * * *\end{array}$ & $\begin{array}{c}0.381 \\
(2.06)^{* *}\end{array}$ & $\begin{array}{c}0.320 \\
(2.22)^{* *}\end{array}$ \\
\hline GP land gini & $\begin{array}{c}-0.224 \\
(2.64)^{* * *}\end{array}$ & & & $\begin{array}{c}-0.253 \\
(2.92)^{* * *}\end{array}$ & $\begin{array}{l}-0.114 \\
(0.38)\end{array}$ & \\
\hline Member of President's party*GP educa & level & $\begin{array}{l}0.013 \\
(0.96)\end{array}$ & & $\begin{array}{l}0.021 \\
(1.33)\end{array}$ & & \\
\hline GP education level & & $\begin{array}{l}0.026 \\
(1.61)\end{array}$ & & $\begin{array}{l}-0.010 \\
(0.39)\end{array}$ & & \\
\hline Member of President's party*GP dur. g & index & & $\begin{array}{c}0.008 \\
(1.83)^{*}\end{array}$ & $\begin{array}{l}-0.005 \\
(0.65)\end{array}$ & & \\
\hline GP durable goods index & & & $\begin{array}{l}0.001 \\
(0.36)\end{array}$ & $\begin{array}{l}-0.001 \\
(0.20)\end{array}$ & & \\
\hline Control variables as in table 2 & Yes & Yes & Yes & Yes & Yes & Yes \\
\hline Fixed effects & District & District & District & District & District & GP \\
\hline Observations & 4,844 & 4,844 & 4,844 & 4,844 & 4,704 & 4,704 \\
\hline R-squared & 0.24 & 0.23 & 0.23 & 0.24 & & \\
\hline Hansen J-test of instrument exogeneity & alue) & & & & 0.26 & 0.47 \\
\hline $\begin{array}{l}\text { F-test of excluded variables in first-stag } \\
\text { Land gini } \\
\text { Interaction term }\end{array}$ & gression & & & & $\begin{array}{c}9.1 \\
407\end{array}$ & 815 \\
\hline
\end{tabular}

$\mathrm{t}$ statistics in parentheses. Standard errors are adjusted for clustering at the village level.

* significant at $10 \% ; * *$ significant at $5 \% ; * * *$ significant at $1 \%$

In columns 2 and 3 the average education level of household heads in the GP and the GP average of the durable goods index, respectively, and the interactions between these variables and membership of the President's party are entered. The coefficients on both interaction terms are positive, and the interaction between the GP-durable goods index and membership of the President's party is significant at the ten percent level. In column 4 all the interaction terms (and main effects) are entered in the same regression. The result is that the interaction between inequality and membership of the President's party remains significant and strong, while the two other interaction terms are completely insignificant. Similar results are obtained when a probit model is estimated and when the landlessness rate is used as the measure of inequality, rather than the land gini (results 
not shown). As stated in the introduction, this is a main result: Party-based clientelism is much stronger in unequal than in equal communities. On the other hand, there is no evidence that it is affected by levels of economic development.

\subsection{Endogenous inequality}

The paper argues that inequality leads to clientelism, but higher levels of clientelism may also reinforce inequality, for example if the least resourceful households are excluded from patron-client relations. This possibility is taken into account by instrumenting current inequality with proxies for inequality in 1991, obtained from the 1991 Census of India. The Census included a classification of full-time workers according to industrial categories. In particular, it is possible to distinguish between people working on their own farm and other workers. It is assumed that workers employed on their own farm as a share of all workers is a good proxy for land inequality in 1991. If land is equally distributed, many people will be small farmers, working on their own farm. On the other hand, if many households have no or only very little land (i.e. land inequality is high), many will be working mainly on other people's farms, or outside agriculture.

The share of workers employed on own family farms can be calculated for both women and men, and both these variables are used as instruments for inequality in 2002. Furthermore, because inequality is interacted with membership of the President's party, the interactions between membership of the President's party and the shares of workers employed on own farms are also used as instruments.

Regressions 5 and 6 reports the results of this exercise, with district- and GP fixed effects. In the estimations with GP fixed effects, the main effect of inequality drop out because it is measured at the GP level. In both regressions the interaction between membership of the President's party and inequality remains significant and positive. 
At the of bottom the table, tests of instrument exogeneity and relevance are reported. The Hansen $J$ test of instrument exogeneity fails to reject the hypothesis that the instruments are exogenous. F-statistics for the tests of joint significance of the instruments in the first stage regressions are also provided. The instruments are below the rule-of-thumb value of 10 in one case, namely in the first stage regression for the main effect of the land gini. However, the shortfall is not large $(\mathrm{F}=9.1)$. In sum, the IV estimations strengthen the case that higher inequality leads to higher levels of political clientelism.

\section{Conclusion and discussion}

The paper makes two main contributions. First, the existence of party-based political clientelism is demonstrated empirically in the context of local governments in India. Discrimination based on party membership is equally or more important than favouritism along lines of religion, caste, occupation, education and place of living. Substantial heterogeneity across states and political parties is uncovered. The measure of political clientelism applied is attractive. It is based on objective and easy-to-measure criteria, as opposed to the perceptions-based measures often applied in other studies of good governance. Second, the paper documents that political clientelism is strongly affected by inequality. In equal communities clientelism is unimportant, but in unequal communities it is pervasive. In contrast, there is little evidence that political clientelism is affected by economic development.

The finding of party favouritism does not imply that political parties in general play a negative role in development. The two states where political clientelism was detected, Kerala and Tamil Nadu, have done relatively well over the past 30 or 40 years in terms of reducing poverty (Ravallion and Datt 2002) and political parties have been instrumental in this progress in several ways, for example by eroding traditional, caste-based patterns of political dominance (Harriss 
1999). It is possible to interpret political clientelism as a "necessary evil". Mobilizing the masses to effect change, such as the removal of a repressive social order, presents a massive collective action problem and perhaps the promise of private benefits is the only effective means of overcoming this obstacle (cf. Olson 1965). As discussed in section 7.3, political clientelism typically replaces previous, even more unequal relationships based on "clientelism of the notables". This being said, the allocation of public resources according to criteria of political affiliation does not correspond well with traditional standards of democracy and good governance. If the benefits from a poverty alleviation program are targeted to members of the ruling party rather than to the poor, the program will not be effective in reducing poverty and improving intra-village distribution.

Determinants of the decision to join a party have not been directly investigated in this paper. However, the findings indicate that it is often prudent to interpret data on civil society activity with a degree of skepticism. While high levels of participation in parties and other civil society organizations could indicate high levels of political awareness and desire to affect public life, rent seeking may also play a role.

To some extent the paper serves as an antidote against the naive "small is beautiful"romanticism which is sometimes behind the push for decentralization. Governance failure exists in local as well as national governments. On the other hand, the paper should not be read as a recommendation against decentralised government. First, it is entirely possible that allocation biases are at least as strong at district-, state- or national levels as it is at the local level, as documented in Bardhan and Mookherjee (2006b) and Galasso and Ravallion (2005). Second, the results reported document that the poverty alleviation program under study is in fact to an important extent targeted to the poor.

The results do indicate, however, that the success of decentralization is likely to depend on implementation of complementary policies, such as land reform, policies to secure 
openness in political and administrative decision making, and reforms to strengthen the media. The call for land reform follows directly from the finding that more equal communities are less prone to political clientelism. The recommendations on introducing openness and strengthening the media stem from the fact that political clientelism is partly a result of local politicians' misuse of discretionary powers. 


\section{Notes}

1. The last, open bracket presents a special problem. However, only one household in the entire sample is in this bracket. It is assigned the value 30 acres.

2. For example, the share of the adult population belonging to a political party or group is 2.0 percent in Japan, 4.9 percent in Great Britain, 6.5 percent in Denmark and 14.5 percent in the United States (World Values Study Group, 1994).

3. Besley, Pande and Rao (2005a) include the sample of elected officials in their estimation sample, whereas this paper does not. They find that households with members who are currently GP politicians are more likely than others to be program beneficiaries. My results, on the other hand, show that households where someone in the (extended) family is or was a politician are less likely than other to benefit. The difference between the results could be explained by the fact that the tendency for politicians to be from an economically privileged background was stronger in the past than it is today (in part because of the reservation system).

4. Apart from the variables indicating whether a households belongs to a scheduled caste or -tribe, data on caste was recorded in "open coding". Answers were not coded in accordance with a predefined list of castes. This entails some inconsistencies in the data, since different, local names and spelling conventions are often used for the same caste. After correcting for these inconsistencies to the extent possible, the 5,180 households in the survey are classified as belonging to 297 different castes. 21 percent of respondents belong to the same caste as the GP president. While this estimate may to some extent be biased downward due to the inconsistencies mentioned, the level of magnitude appears realistic.

The level-of education variables distinguishes between three categories: No schooling; 1 to 6 years of schooling; and more than six years of schooling. The variable takes the value one if the household head is in the same category as the President, and zero otherwise. 


\section{References}

Alexander, K.C. (1989) Caste mobilization and class consciousness. The emergence of agrarian movements in Kerala and Tamil Nadu. In: Frankel, F. and Rao, M.S.A. (Eds.) Dominance and State Order in Modern India, Vol. 1 (Delhi: Oxford University Press).

Bardhan, P. and Mookherjee, D. (2003) Political economy of land reform in West Bengal. Boston University, mimeo.

Bardhan, P. and Mookherjee, D. (2006a) Decentralization to local governments in developing countries: A comparative perspective (Cambridge, MA: MIT Press).

Bardhan, P. and Mookherjee, D. (2006b) Pro-poor targeting and accountability of local governments in West Bengal. Journal of Development Economics 79(2), pp. 303-327.

Bardhan, P., Mitra, S., Mookherjee, D. and Sarkar, A. (2008): Political participation, clientelism and targeting of local government programs: Analysis of survey results from rural West Bengal. Mimeo, Boston University.

Besley, T. and Burgess, R. (2002), The political economy of government responsiveness: Theory and evidence from India. Quarterly Journal of Economics 117, pp. 1415-1451.

Besley, T., Pande, R., Rahman, L. and Rao, V. (2004), The politics of public goods provision: Evidence from Indian local governments. Journal of the European Economic Association 2(2-3), 416-426.

Besley, T., Pande, R., Rao, V. (2005a) Political selection and the quality of government, in: World Bank: The political economy of Gram Panchayats in South India. Results and policy conclusions from a research project (Washington DC: The World Bank).

Besley, T., Pande, R. and Rao, V. (2005b) Participatory democracy in action: Survey Evidence from South India. Journal of the European Economic Association 3(2-3), pp. 648-657.

Besley, T., Pande, R. and Rao, V. (2007) Just rewards? Local politics and public resource 
allocation in South India? Mimeo, STICERD.

Brass, P. (1990) The politics of India since Independence. Second edition (Cambridge: Cambridge University Press).

Chandra, K. (2004) Why ethnic parties succeed. Patronage and ethnic head counts in India (Cambridge, U.K.: Cambridge University Press).

Crook, R.C., and Manor, J. (1998) Democracy and Decentralisation in South Asia and West Africa. Participation, Accountability and Performance (Cambridge: Cambridge University Press).

Downs, A. (1957) An economic theory of political action in a democracy. Journal of Political Economy, 65(2), pp. 135-150.

Esteban, J. and Ray, D. (2006), Inequality, lobbying and resource allocation. American Economic Review 96(1), pp. 257-259.

Foster, A.D. and Rosenzweig, M.R. (2001), Democratization, decentralization and the distribution of local public goods in a poor rural economy, PIER Working Paper 01-056.

Galasso, E. and Ravallion, M. (2005) Decentralized targeting of an antipoverty program. Journal of Public Economics 89(4), pp. 705-727.

Graziano, L. (1973) Patron-client relationships in Southern Italy. European Journal of Political Research 1(1), pp. 3-34.

Grossman, G.M. and Helpman, E. (1996) Electoral competition and special interest politics. Review of Economic Studies 63(2), pp. 265-286.

Harriss, J. (1999) Comparing political regimes across Indian states. A preliminary essay. Economic and Political Weekly, November 27, pp. 3367-3377.

Karnataka State Election Commission, http://karsec.gov.in/rurallocal-fs.html

Kaufmann, D., Kraay, A. and Mastruzzi, M. (2004) Governance matters III: Governance indicators 
for 1996-2002 (Washington D.C.: The World Bank).

Kohli, A. (1987) The state and poverty in India. The politics of reform (Cambridge: Cambridge University Press).

Kohli, A. (1990) Democracy and Discontent. India's Growing Crisis of Governability (Cambridge: Cambridge University Press).

Kumar, D. (1965) Land and Caste in South India. Agricultural Labour in the Madras Presidency During the Nineteenth Century (Cambridge: Cambridge University Press).

Kurer, O. (1996) The political foundations of economic development policies. Journal of Development Studies 32(5): pp. 645-668.

La Ferrara, E. (2002) Inequality and group participation: theory and evidence from rural Tanzania. Journal of Public Economics 85(2), pp. 235-273.

Lemarchand, R. and Legg, K. (1972): Political clientelism and development: A preliminary analysis, Comparative Politics 4(2): pp. 149-178.

Lindbeck, A. and Weibull, J. (1987) Balanced-budget redistribution as the outcome of political competition. Public Choice 52(3): pp. 273-297.

Markussen, T. (2009) Institutions in development: Five essays on politics, property rights and prosperity, $\mathrm{PhD}$ Dissertation, University of Copenhagen.

Manor, J. (1999) The political economy of democratic decentralization (Washington DC: World Bank).

Office of the Registrar General, India, Census of India, 1991 (New Delhi).

Olson, M. (1965) The logic of collective action (Cambridge, MA: Harvard University Press).

Platteau, J.P. (1995) An Indian model of aristocratic patronage. Oxford Economic Papers 47(4), pp. 636-662.

Platteau, J.P. and Abraham, A. (2002) Participatory development in the presence of endogenous 
community imperfections. Journal of Development Studies 39(2), 104-136.

Powell, J.D. (1970) Peasant society and clientelist politics. American Political Science Review 64(2), pp. 411-425.

Ravallion, M. and Datt, G. (2002) Why has economic growth been more pro-poor in some states of India than others? Journal of Development Economics 68(2), pp. 381-400.

Robinson, J.A. and Verdier, T. (2002) The political economy of clientelism. CEPR Discussion Paper.

Staiger, D. and Stock, J.H. (1997) Instrumental variables regression with weak instruments, Econometrica 65(3), pp. 557-586.

Subramanian, N. (1999) Ethnicity and populist mobilization. Political parties, citizens and democracy in South India (Delhi: Oxford University Press).

Suri, K.C. (2002): Democratic process and electoral politics in Andhra Pradesh, India, Overseas Development Institute Working Paper 180.

Tharakan, P.K.M. (2004) Historical hurdles in the course of the People's Planning Campaign in Kerala, India. In: Harriss, J., Stokke, K., Törnquist, O. (Eds.) Politicising democracy. The new local politics of democratisation (Basingstoke: Palgrave Macmillan).

Wantchekon, L. (2003) Clientelism and voting behavior: Evidence from a field experiment in Benin. World Politics 55(3), pp. 399-422.

Weiner, M. (1967) Party Building in a New Nation (Chicago: University of Chicago Press)

Weingrod, A. (1968) Patrons, patronage and political parties. Comparative Studies in Society and History 10(4), pp. 377-400.

Widlund, I. (2000) Paths to power and patterns of influence. The Dravidian parties in South Indian politics (Uppsala: Uppsala University Library).

Wooldridge, J.M. (2002) Econometric analysis of cross section and panel data (Cambridge. MA: 
MIT Press).

World Bank (2005) The political economy of Gram Panchayats in South India. Results and policy conclusions from a research project (Washington DC: The World Bank).

World Values Study Group (1994) World values survey, 1990-93 (Inter-university Consortium for Political and Social Research, Ann Arbor, Michigan). 